Please do not remove this page

RMIT

UNIVERSITY

\title{
Indigenous people and the miserable failure of Australian planning
}

PORTER, Libby

https://researchrepository.rmit.edu.au/esploro/outputs/9921860536101341/filesAndLinks?institution=61RMIT_INST\&index=null

PORTER, L. (2017). Indigenous people and the miserable failure of Australian planning. Planning Practice and Research, 32(5), 556-570. https://doi.org/10.1080/02697459.2017.1286885

Document Version: Accepted Manuscript

Published Version: https://doi.org/10.1080/02697459.2017.1286885

Repository homepage: https://researchrepository.rmit.edu.au

(C) 2017 Informa UK Limited, trading as Taylor and Francis Group

Downloaded On 2023/04/26 23:56:44 +1000 
Thank you for downloading this document from the RMIT Research Repository.

The RMIT Research Repository is an open access database showcasing the research outputs of RMIT University researchers.

RMIT Research Repository: http://researchbank.rmit.edu.au/

\section{Citation:}

Porter, E 2017, 'Indigenous people and the miserable failure of Australian planning', Planning Practice and Research, vol. 32, no. 5, pp. 556-570.

See this record in the RMIT Research Repository at:

https://researchbank.rmit.edu.au/view/rmit:48339

Version: Accepted Manuscript

Copyright Statement:

C 2017 Informa UK Limited, trading as Taylor and Francis Group

\section{Link to Published Version:}

https://dx.doi.org/10.1080/02697459.2017.1286885 
Indigenous people and the miserable failure of Australian planning Libby Porter

Published in 2017, Planning Practice and Research 32(5):556-570

Affiliation: Centre for Urban Research, RMIT University

E: libby.porter@rmit.edu.au 


\title{
Indigenous people and the miserable failure of Australian planning
}

Libby Porter

\begin{abstract}
Major changes in Australian law and significant research efforts have repositioned Aboriginal and Torres Strait Islander peoples as important actors in planning. Yet this has barely penetrated the consciousness of the mainstream professional community. Current requirements for professional competencies and planning curricula fall well short of preparing planners to productively engage with Indigenous people. The profession itself barely acknowledges the significant changes advanced in Indigenous studies and planning, and the new imperatives. This paper details the contemporary position of planning practice in Australia with regard to Indigenous people and considers the changes required to more justly engage with Indigenous rights.
\end{abstract}

\section{Keywords}

Indigenous people, professional planning, planning education, Australia

\section{Introduction}

Over the past four decades, major legal shifts alongside significant efforts in planning scholarship have signified the importance of Indigenous people, law, land and knowledge to the practices and systems of planning. In settler-colonial contexts like Australia, where this paper is focused, material changes in property and land law, plus obligations to protect cultural heritage and native title rights have crucial implications for everyday planning practice. Planning has also become a key site of focus for Indigenous peoples asserting and practicing their own rights and responsibilities. And planning scholarship has now established a small but substantial body of work attesting to the complicity of planning in colonial processes (Porter 2010; Jackson 1997), the relationship between 
planning and Indigenous peoples (Jojola 2008; contributions to Walker et al. 2013; Peters \& Walker 2005; Wensing 2012; Stuart \& Thompson-Fawcett 2010) and the important role of planning in the contemporary lives of Indigenous people (Porter 2006a; Porter \& Barry 2014; Wensing \& Porter 2015; Wensing 2013; Barry 2012; Howitt \& Lunkapis 2010; Sandercock \& Attili 2010).

Yet these imperatives, socio-legal changes and new research evidence have barely penetrated the consciousness of the vast majority of the professional planning community in Australia. While there are some small and important exceptions, the industry largely operates under a settler-colonial business-asusual model, as if Aboriginal and Torres Strait Islander peoples, rights and knowledge were of little interest or consequence to their practice. Planning education has also singularly failed to address these new imperatives. Current requirements for professional competencies and planning curricula fall well short of preparing planners to productively engage with Indigenous people. In short, we continue to practice planning, and produce new planners, in ways that blatantly practice the imperatives and logics of colonisation.

None of these claims are new. Many scholars and practitioners in Australia and across many other settler-colonial contexts have been arguing this case for years (Porter 2010; Porter 2006b; Wensing 2013; Wensing \& Porter 2015; Sandercock 1998; Jojola 2008; Matunga 2013; Howitt \& Lunkapis 2010; Jackson 1996; Jackson 1998). Yet still, little has changed. As has been recently argued, the link between any kind of planning research and practice is weak (Taylor \& Hurley 2015). A similarly weak relationship appears to exist between the large body of evidence linking planning and Indigenous peoples' connections to place and mainstream planning practice.

This paper addresses these ongoing silences and omissions. It builds on the argument that regressive drivers of planning practice such as neoliberalism and neo-colonialism do not sit easily with accepting critical research (Whitzman this issue, Hurley and Taylor this issue). The paper advances this argument in three inter-related ways: first by establishing four clear and compelling obligations 
that the planning profession can no longer ignore. These provide the imperatives for action. Second, by exposing in some detail, the miserable failure of planning to attend to those obligations. In this regard, the paper analyses the resounding lack of response across the profession. Third, the paper specifies some urgent next steps for planning to more justly engage with Indigenous rights, including overcoming the barriers of the links between research and practice.

\section{Why it matters: The obligations of Australian planning}

Indigenous societies and non-Indigenous planning systems share a common interest: place. All of the first peoples who have been systematically dispossessed by settler-colonialism, for example, are intrinsically place-based and place-making systems of culture and law. The centrality of place and landscape to Indigenous life, experience, knowledge, law and futures has been documented and discussed in many different fields and by many different voices.

In the Australian context, this place-based concept has come to be called country, a signifier of the complexities and particularities of Indigenous place-based relationships and responsibilities. Briefly, country encapsulates not only land but also sea, sky and waterways and all of the living things that together make that place. Country is a living sentient thing in and of itself, a "nourishing terrain....with a yesterday, today and tomorrow, with a consciousness, and a will toward life" (Rose 1996, p.7). This inter-connection means that land is not merely a flat surface upon which life is enacted, but instead intrinsic to knowledge, law and relationships. This is a notion of co-becoming, best articulated in recent work published with country as an active author (see Bawaka Country et al. 2016). The concept also points to the discrete yet interconnected socio-cultural and economic systems each with responsibility for and with specific places. The point is that just like planning, this is a relationship of human systems of governance to place.

While that interest may be shared, the forms of knowledge, practice, law and values are profoundly different (sometimes incommensurably so). Moreover, 
western planning has never shared its authority and responsibility for place with Indigenous societies. In Australia, the planning profession has never acknowledged that it co-exists with another system of place-making and placegovernance, nor has much effort been given to rethinking planning from the departure point of shared co-existence.

Instead, the planning profession in Australia has done the opposite: the practices that constitute non-Indigenous planning systems were centrally important to the early phases of dispossession that characterized every British settler-colonial project including Australia's. And planning continues to be a site that is persistently used to resettle colonial authority and marginalize Indigenous people. As I have asked with Ed Wensing in previous work: "How could a profession that is so fundamentally about the relationship between people and their land base simply not see the importance of Aboriginal and Torres Strait Islander people's intrinsic connection to and responsibility for land?" (Wensing \& Porter 2015, p.2). What we have then is a situation where two co-existing systems of place-making and place-governance actually exist, yet one operates in a dominant and powerful form to the near-total exclusion of the other, with deeply marginalising and unjust consequences.

This situation is present and persistent right now in Australia as in other settlercolonial states with a similar history. It signals a number of unmet obligations of planning to Aboriginal and Torres Strait Islander peoples. It is not a matter of mere academic curiosity that planning systems must begin to think about how to make amends, be held accountable for, redress and reconcile with Aboriginal and Torres Strait Islander peoples. Nor is it a matter of moral obligation to redress past and present wrongs, though that is important too. This obligation stretches across dimensions of accountability, shared co-existence, international law, and local legislative and policy compliance. The following sub-sections specify these obligations in turn, providing the imperative and justification for why it matters that both the planning profession and education communities urgently engage with the realities of Indigenous lives and lands. 


\section{The obligation of accountability}

Any form of colonization requires the alienation of land in the interests of colonial possession and domination. In Australia, like in other British settler states, land was stolen from first peoples, and those peoples were subject to barbaric violence in order to do that thieving. These histories and practices are well documented. Alongside and often inter-related to those practices, were the other forms of work required to usurp land for the purposes of white settlement, and this is where the complicity of planning and urban settlement is most explicitly revealed. Settling land through occupation, defining boundaries, mapping, renaming, erecting fences, constructing buildings, using land and resources formed the basis of securing land from its original custodians. Again, there is a well established literature that makes this point very clearly (Harris 2002; Ryan 1996; Carter 1987; Weaver 1996; Dorsett 1995; Blomley 2004; Byrne 2003). Urban development was intrinsically important to this effort.

This shows how important the ordering of space, place and settlement was for the success of colonial endeavours - 'success' here meaning of course the dispossession of Indigenous people, the usurpation of their authority and governance systems, and their marginalisation. As I have documented closely in earlier historical work (see Porter 2010 especially chapter 3), the work of a nascent planning profession was crucial to that project. Planning of course did not yet exist as a distinct profession, but the practices and sensibilities that we now come to recognize as planning were certainly already in operation. And indeed that work, undertaken experimentally as it was in settler-colonial contexts, has come to produce a particular kind of planning mentality in contemporary settler states like Australia. Planning, in the sense of making 'blank slates' from which new futures could be imagined, was not taken to the colonies by European powers, but was made in the colonies through experimentation with land theft and speculation.

It is important to remember that this project was not completed back in 'colonial' times. The nature of the settler-colonial project is alive today, because in a 
settler-colony non-Indigenous authority and dominance has to be continuously reasserted to survive. This is achieved via ongoing structures and processes that continue to dispossess and marginalize Indigenous peoples. Planning remains complicit in any number of mechanisms that do this work. Examples include usurping Aboriginal reserves for white township use as in central British Columbia (Sandercock \& Attili 2010), or in Darwin (Jackson 1997); displacing urban Aboriginal communities through gentrification and urban renewal such as in East Perth (Byrne \& Houston 2005; Hillyer 2007), Sydney (Anderson 1993), and Vancouver (Blomley 2004) and reclaiming Aboriginal reserves on the fringes of regional centres to accommodate new urban growth (Jackson 1997).

These histories and contemporary situations of planning reveal an obligation of accountability and redress that planning holds towards the Indigenous societies it has worked to systematically steal from and marginalize.

The obligation arising from co-existence

The section above has detailed how the lands over which planning in Australia now occurs were stolen from Indigenous peoples. Their sovereignty was never ceded, their country never willingly traded or given. It is true that the legacy of colonisation in places like Australia has been one of cultural destruction with languages lost or decimated, cultural practices and law systems disrupted, and people and their kinship relations dispersed and fragmented. However, it is also true that despite those profound disruptions and losses, Aboriginal and Torres Strait Islander societies continue to exist, and continue to assert their jurisdiction over and responsibility for their places.

The responsibilities and relationships with place that Indigenous societies hold may have changed but they have not gone away. They are often being reconstituted in contemporary forms, with extraordinary efforts underway toward reclamation of language, story, knowledge and practice. Planning must come to just terms, then, with the fact that it is not the sole jurisdiction, 
knowledge base or set of laws that govern any particular place, regardless of whether formally recognized not.

With this understanding in mind, a useful framework for thinking about the space between the non-Indigenous planning system and Indigenous domains is as a mode of co-existence. That they do so in ways that are rarely common and often fundamentally different presents a core challenge to planning (Howitt 2006). Co-existence advances a "critical yet hopeful conceptual framing" (Porter \& Barry 2016, p.5) for planning with Indigenous peoples. By this, co-existence can be seen to hold in tension two dimensions: first, that the geographies of settler-colonies like Australia are hardly a level playing field. Therefore even well-meaning engagements between planners and Indigenous communities are already structured by legacies of colonial domination and resistance. Second, that this does not necessarily foreclose the rest of the story - it will always be possible to negotiate different terms, new approaches and find the opportunities for transforming social relations. While the past is most certainly a legacy, the future might always be different.

\section{The human rights obligation}

In 2007, the United Nations passed the Declaration on the Rights of Indigenous People (UNDRIP). This underscores the right of all peoples to self-determination in the pursuit of economic, social and cultural development. Especially, it affirms the right of Indigenous peoples to maintain and strengthen their relationships to their traditional territories. A crucial procedural point arising from the UNDRIP is the principle of 'free, prior and informed consent', a much stronger obligation than merely consultation (Wensing and Porter 2015), signalling the need for new approaches. Negotiating free, prior and informed consent on planning interventions would require sustained relationships with Indigenous communities and the recognition of the distinct social and governance arrangements of those societies. 
The broader question of power that the human rights framework signals and indeed reproduces has come under sustained critique from a number of quarters, most importantly Indigenous scholars (Newcomb 2011; Watson 2011) who have pointed out it is at best illusory, and at worst fundamentally imperialist. A central concern of these critiques is the territorial conflict that is the primary tension between settler-colonial states, such as Australia, and the Indigenous peoples those states continue to colonize. The state, as Watson points out, is "intent upon upholding its territorial integrity" (Watson 2011, p. 621) but that upholding occurs at the profound cost of Indigenous peoples' prior ownership. Thus, "the 'peace of society' is secured through our containment or eradication" (ibid).

\section{The legal and policy obligation}

Planning operates in a legal and policy context and that imposes specific obligations in relation to Aboriginal and Torres Strait Islander peoples in Australia. Three in particular are worthy of brief consideration: land rights; native title; and cultural heritage. Each is a response to the claims and demands that Indigenous peoples have been making, in different ways, to settler-colonial states since invasion. They are, in the main, fundamentally inadequate as any critical analysis reveals (Povinelli 2002; Coulthard 2014; Watson 2015). The important point here is that they present specific obligations and requirements for planning.

Indigenous property rights are now well established in Australian law and have created what some have called a 'land titling revolution' (Altman 2014). This has produced a renewed Indigenous estate covering more than 30\% of the Australian continent (Altman \& Markham 2015), principally in remote and rural areas. This figure is likely to grow. How this has come about is crucial for the planning community to understand. 
The period of the 1960s and 1970s in Australia saw the sustained emergence of a distinct campaign for land rights by Aboriginal and Torres Strait Islander peoples (Foley \& Anderson 2006). One of the seminal moments in the emergence of what has been called the land rights era was the Wave Hill walkoff in 1966. The Gurindji people of the Victoria River area in the Northern Territory spent 9 years in a strike action against the British company Vesteys for rights to their land and humane pay and conditions for their labor.

During the same time, in 1969, the Yirrkala people launched a court action for their lands in north-east Arnhem Land. They lost, in an infamous decision by Justice Blackburn in Milirrpum v Nabalco, and in 1972 the McMahon government sought to further entrench the dispossession of Indigenous peoples by refusing the notion that Aboriginal people could be granted freehold to land and instead proposed leases. This triggered the now famous and long-standing Tent Embassy campaign, setup on the lawns of Old Parliament House in Canberra. These and other crucial actions eventually resulted in momentous change with the passage of perhaps the most important piece of land rights legislation in Australia, that of the Aboriginal Land Rights (Northern Territory) Act 1976 (Cth).

With the exception of Western Australia, all Australian States and Territories now have some kind of legal mechanism for the granting of lands to Aboriginal people, although it is a highly variable suite. The important point here is that planners have to work in a legal context where Aboriginal and Torres Strait Islander peoples have legally defined and protected rights and responsibilities under Australian law. Many of these frameworks produce some degree of autonomy for Indigenous people in relation to land use and management (Altman \& Kerins 2012). They each add a crucial but complex layer to any planning intervention.

In 1993 a quite different legal framework was developed that recognizes in Australian law the form of title held by Aboriginal and Torres Strait Islander peoples under their own laws and customs. Called 'native title', where Aboriginal or Torres Strait Islander communities are successful in their native title claims, 
the state agrees to recognize and uphold in Australian law, their rights and obligations according to their own customs. This is a quite different form of recognition than the land rights noted above, as native title is not an 'act of grace or favour' by the state but recognition of something that pre-exists and survives colonization.

Native title thus presents a new property framework within which planners now operate, yet there has been only limited discussion of this within the planning profession. Guidance notes were developed in 1997 in partnership with the professional association for land valuers (Wensing \& Sheehan 1997), and some workshops were undertaken. There was some effort put into suggesting further action (Maclean 1997), but little change ensued. Moreover, native title is a dynamic area of law, seeing many significant shifts in the past 20 years (see contributions to Brennan et al. 2015). An analysis of the profession's magazine, previous conferences and websites, however, reveals very little attention has been paid to native title since that initial flurry of activity.

In addition to land law and property rights, each State and Territory in Australia has specific and distinct legislative requirements for protecting and managing cultural heritage (McGrath 2016). These often create an intersection between planning and Indigenous peoples interests and values. Protecting and valuing culture, place and the evidence of pre-invasion occupation enormously important to Indigenous communities in Australia. Cultural heritage management often falls well short of their aspirations and much has been written on the limitations of cultural heritage as a regime (Smith 2000; Smith 2004; Byrne 1996; McGrath 2016). The point here, however, is that these frameworks exist and create obligations for planning, obligations that are often ignored or misunderstood. Victoria, discussed further below, is a particularly interesting case because it creates an explicit link with statutory planning.

\section{How Australian planning is responding}


What is the response of the Australian planning profession, including the planning education community, to these imperatives? What kinds of steps have been taken to address these obligations? In this section I address three principle areas where planning would need to consider a response: policy and legislation, education and curricula, and the profession itself.

\section{Planning policy and legislation}

Planning is the responsibility of States and Territories in Australia and therefore the legislative and policy system is diverse across the country. There is a nearuniversal silence on Aboriginal and Torres Strait Islander rights, interests and responsibilities across each of them. This silence is both stark and startling given the imperatives and histories briefly outlined above. Planning law continues to operate in Australia as if Aboriginal and Torres Strait Islander peoples do not exist and as if their continuing rights, responsibilities, knowledges and cultures have no bearing on a sustainable future for Australian cities and regions.

This is especially pertinent in metropolitan areas. Urban structure plans, planning policy frameworks, masterplans and precinct plans never even so much as mention that all of these planning activities are undertaken on lands that are unceded and over which Indigenous peoples continue to assert and practice their rights and responsibilities. The metropolitan plan for Sydney, for example, gestures toward a vague pride in 'our' Aboriginal heritage once, and a plan for a new Indigenous cultural centre as one component of a larger flagship development (NSW Government 2014). Plan Melbourne makes passing mention of Aboriginal interests five times in a 200-page document, most of which are cursory backwards glances acknowledging prior presence, with one initiative section on Aboriginal heritage (see 4.7.2 of Government of Victoria 2014). The overwhelming situation is one of silence, creating a persistent complicity with the colonialist work of dispossession, marginalisation and oppression.

There are two specific and interesting exceptions to this silence. One is the insertion of Aboriginal cultural heritage protection in the Planning and 
Environment Act 1987 (Vic). This was a result of consequential amendments arising from the Aboriginal Heritage Act 2006 (Vic), which established a new structure and system for protecting Aboriginal cultural heritage across the State. It means that on certain categories of development and only in certain places, a recognized Aboriginal organisation must be involved in considering and approving a Cultural Heritage Management Plan (CHMP) linked to the development application process.

These provisions enable a quite limited, but nonetheless important, moment in which the interests of Aboriginal people have statutory weight within the planning system (see Porter and Barry 2016 for a deeper analysis). While the provisions have been underway for 10 years now, and have been amended after a recent review, it remains the case that Aboriginal organisations and traditional owners continue to battle with a very poor level of awareness and understanding by planners of these requirements and why they matter. The problems often stem from a very compliance-focused attention to the Act, as demonstrated in the language of risk management exemplified in the Victorian Government's current advice to development proponents about cultural heritage protection (http://www.aav.nrms.net.au/aavVoluntaryPlans.aspx).

The second more far-reaching exception was the passage, in May 2016, of new planning legislation in Queensland, the Planning Act 2016 (QId). This legislation explicitly incorporates "protecting and promoting Aboriginal and Torres Strait islander knowledge, culture and tradition" (S.5 (2)(d)) as a central purpose of planning. It is too early yet to see the implications of that inclusion within planning practice in Queensland. However, it is clear that it means any planning activity undertaken under the auspices of the Act in Queensland will need to comply with the purpose of protecting and promoting Indigenous cultures and knowledges, demanding new approaches (Wensing 2016).

Planning education 
A student finishing a planning degree somewhere in Australia in 2016 would most likely not have been exposed to any content in their studies about Aboriginal and Torres Strait Islander cultures or land management systems. Indigenous knowledge systems, methods of environmental care and land-use are virtually unheard of in planning degrees. Similarly, historical perspectives on planning that reveal the colonial context in which the discipline is embedded are absent. Little attention is paid to the dynamic and complex legal and policy frameworks described above.

Typically, there is a unit or two offered more generally across the institution which provides an introduction to some of the issues of colonisation, racism and contemporary challenges faced by Indigenous people today. A very small number of planning degree structures have required students to take that unit, but most suggest it as an elective. Some individual courses now include a limited content for example on cultural heritage, though it is by no means universal. Overall, the picture is patchy and at least in part dependent on the particular interests, skills and proclivities of individual educators. In rare places, specific courses have been developed that explicitly address the rights, responsibilities and cultures of Indigenous peoples. Institutions such as James Cook University, in Australia's north, have developed some of the leading educational units across the country that explicitly address the intersection between Indigenous lives and the western planning system.

In the main, however, the Australian planning education system has a very poor scorecard on these matters. There has been remarkably little effort to take seriously, and resource, the obligation to change practices of education that have been so consistently found to produce poor outcomes for Indigenous peoples. A key reason for this impoverished situation of planning education in Australia is the lack of leadership and direction from the accrediting body, the Planning Institute of Australia (PIA). Calls for PIA to require planning degrees to include mandatory Indigenous course content are not new. Sheehan and Wensing have called for this in both planning and valuation professions (Sheehan \& Wensing 1998) with little result. In 2010, a PIA Indigenous Planning Working Group 
prepared a discussion paper, setting out what needed to be considered for planning education in this regard. The recommendations were never implemented, and the Working Group disbanded because of the disillusionment many members felt with PIAs lack of response (pers comm Ed Wensing 2015).

It has been only in the 2016 review of course accreditation procedures that it looks more hopeful that all planning courses will be required to include content that covers at least the basics of planning's obligations with regard to Indigenous rights. This raises challenges for the appropriate delivery, in partnership with Aboriginal and Torres Strait Islander peoples, of those courses. PIA is as yet to fully grasp these challenges and respond with adequate resourcing, commitment and national leadership.

\section{Planning industry and profession}

What might new practices and professional competencies look like, if they responded adequately to the obligations and imperatives discussed above? While a crucial question, it remains vital to not fall prey to simple 'tick-box' solutions couched in a language of best practice. If one thing is clear about working toward an ethic of genuine co-existence, it is the vital importance of relationships that respond to local specificity, not a list of do's and don'ts (Howitt et al. 2013; Porter \& Barry 2016). Planning must work to develop its own capacities in this area.

One of the ways that organisations and corporations have sought to address this is through Reconciliation Action Plans. Sometimes referred to as RAPs, these documents are often filled with motherhood statements and often lack clarity or authority in terms of implementation. They can be read as merely a tokenistic effort to address questions of justice for Indigenous peoples. Despite their shortcomings, they might also be read as markers of an organisation's willingness to at least consider its role and obligations. In that sense, an absence of a Reconciliation Action Plan sends a strong message of an active resistance to 
taking even the smallest of steps toward a more meaningful relationship with Indigenous peoples.

PIA is the peak body representing and governing the profession of planning in Australia, and says that its role is guiding professionals to create better communities (www.planning.org.au). PIA does not have, at the time of writing, a current Reconciliation Action Plan. Nor does it have any national or professionwide strategy or statement about the intrinsic link between the activities of the planning profession, and the lives of Aboriginal and Torres Strait Islander peoples in Australia. There is no national employment strategy for Indigenous people in planning, and little effort has gone into encouraging Indigenous students into planning. Consequently there are only a tiny number of Indigenous planning practitioners, few Indigenous planning researchers, and not a single senior Indigenous scholar in the field of planning anywhere in Australia at the time of writing.

Very few Aboriginal or Torres Strait Islander voices are heard in mainstream planning discussions. It was only in 1983 at the national congress of the thennamed Royal Australian Planning Institute (RAPI) that what was described as the "first ever paper by an Aboriginal to a group of Australian planners" was given (Colman 1984, p.29). A content analysis of past congresses reveals that discussion about Aboriginal and Torres Strait Islander rights and responsibilities for land are rare. The main exception was the 2013 National Congress, at which Chief Justice of the High Court Robert French gave a keynote address on native title and planning, and a one-day workshop was co-hosted with the Australian Institute of Aboriginal and Torres Strait Islander Studies (AIATSIS).

Neither has PIA sought to lead a national conversation to engage members of the profession in a meaningful way with Indigenous communities. Analysis of the national congress proceedings indicate that while there are occasional individual presentations that explicitly look at the relationship between planning activities and Indigenous peoples, there are no dedicated sessions to that topic, and no evidence that the profession uses the Congress to develop its knowledge. 
A search of the PIA website reveals that Aboriginal and Torres Strait Islander interests are mentioned in only a handful of places and documents. There was a small flurry of activity in the profession, led mostly by Ed Wensing (cites), after the profession realized that native title was an important consideration for planners. While a Native Title Reference Group was mooted in the late 1990s (Maclean 1997) it appears to have never eventuated. When major native title or other Indigenous land interests news occurs, PIA is silent on these as if they had no real implication for the operation of the profession. According to the online archive, there is not a single press release from PIA in 2014, 2015 and 2016 that acknowledges the impact of the many landmark decisions or changes in native title or cultural heritage for planning during that time.

A content analysis of the professional journal, Australian Planner and its previous titles, reveals that Aboriginal and Torres Strait Islander people are mentioned approximately 200 times between 1958 and 2016. Many of these are largely empty references: for example, they appear because of the name of an Act or reference to a Ministerial portfolio that includes those words. There are 20 substantive pieces (13 research articles, 5 book reviews and 2 policy briefings) that have dedicated and intentional detail on Indigenous issues and two letters to the editor.

A further 18 pieces are news items with small advertisements or points of information about matters that have an Aboriginal focus. Many of these have explicitly racialized overtones or make a tangential reference in a manner that diminishes Indigenous experience and obscures the obligations of planning. In short, there appear to be only 38 substantive references to the experiences of Aboriginal and Torres Strait Islander peoples and the obligations of planning in the pages of the profession's major publication from 1958 to 2016, many of them by the same people. This amounts to merely $0.59 \%$ of the journal, based on assumptions about length of an average volume. While there is of course error in this count, the picture is strikingly clear: the mainstream profession is extremely poor at engaging and responding to Indigenous rights and interests. 
At the local level there are some interesting and important responses, albeit small. In 2015, the Western Australian chapter's conference was held in Broome, a small regional city undergoing profound changes for planning because of a historic native title settlement for the Yawuru people. Yawuru are now one of the major landowners in the town and are pushing for innovative shared planning governance arrangements in Broome and its region. Native title and its implications for planning was a significant theme at the 2015 WA conference. The West Australian Planning Commission has also recently moved to establish an Indigenous interest representative on the committee, which places an Indigenous voice on this important government planning authority. In Victoria, a scholarship program for Aboriginal and Torres Strait Islander students has been established, to encourage Indigenous people to study planning and support them with both a grant and access to paid work experience in a regional council.

The picture I have painted here will no doubt have excluded important exceptions to this overarching story. Certainly there are innovative projects and partnerships underway around Australia, each advancing different approaches. Excluding those is not intended as a dismissal, but instead to highlight that they are exceptions. The mainstream planning profession and industry has yet to respond adequately to the obligations before it.

\section{Toward an agenda for change}

The path toward a just relationship and redress for land and cultural injustice on the terms of Aboriginal and Torres Strait Islander peoples in Australia is not a simple one. Indigenous scholars urge radical forms of decolonising practice and communities are creatively using planning systems to achieve their aspirations. All of these voices teach planning education, research and professional practice lessons of profound importance: to recognize that the first peoples of Australia continue to practice their own structures and systems of land governance, law and forms of knowledge, and their own land use and management priorities. 
These co-exist alongside mainstream planning, even if they are not formally recognized, or even visible.

Based on the analysis that I have presented in this paper, however, the planning community in Australia is a strikingly long way from even beginning the journey toward appropriate forms of redress. Consequently, the scope of change required is inter-generational, demanding commitment and strategic resourcing across generations of planning professionals to come. The possible pathways for this inter-generational, cultural, and structural change required must be mapped out elsewhere. My purpose in concluding this paper is a little more prosaic, focused on some initial steps many of which might usefully be articulated in a new PIA Reconciliation Action Plan as an urgent priority.

First, is to takes steps that acknowledge the complicity of planning in the dispossession of Aboriginal and Torres Strait Islander peoples. This task of (re)education is of singular importance, for without deep reflection on that complicity, efforts toward inclusion of Aboriginal and Torres Strait Islander peoples in planning processes will inevitably be tokenistic. Two obvious opportunities present themselves as initial steps. First, redesign the way planning history is taught in planning schools, and second resource a national program of professional education to expose a wider range of existing practitioners to the effects of settler-colonial planning systems upon Indigenous lives and lands.

This should only be undertaken in close partnership with Aboriginal and Torres Strait Islander peoples. A good step would be for PIA to establish and resource a standing Indigenous advisory or working group that works directly with the PIA Board. Such a group would provide a forum for the voice of Aboriginal and Torres Strait Islander people, including planning practitioners, to speak directly and at a high level to the profession; ensure that dedicated, timely and relevant content about Indigenous peoples rights and interests are represented at every PIA national congress; and drive new strategic directions in relation to Indigenous engagement. A related step would be to develop, fund and run an 
ongoing program of cultural awareness and safety training for planning practitioners across Australia including PIA senior leadership, President and Board. Such training has long been considered a basic first step in developing cultural competency and capacity within non-Indigenous communities of practice.

Second, is to address the major gaps in planning education in Australia and mandate that planning graduates have core competencies in the issues addressed in this paper. This should include: new historiographies of planning that more honestly account for the role of planning in dispossession and marginalisation; the survival of Aboriginal and Torres Strait Islander law, culture and systems of land governance and the contemporary forms of revival these take; changes in Australian law of import to planning, specifically land rights mechanisms, native title rights and interests, and cultural heritage; and an appreciation of the expectations and requirements of contemporary Aboriginal and Torres Strait Islander communities of the non-Indigenous community when operating on their lands and waters.

Other papers in this special issue address the importance of partnership, collaboration and process design to co-create a stronger research-policyeducation nexus. March (this issue) in particular offers the argument that transformation comes from the intersection of education, research and practice. Here, too, that nexus offers positive avenues for the relationship between planning practice and Indigenous people. Having said that, the colonial context must be acknowledged as continuing and real, with material impacts and unique dynamics. It cannot be wished away by nice processes and inclusive education, though both are important to its transformation.

Related to the gap in educational content is the considerable lack of Aboriginal and Torres Strait Islander students completing planning degrees. This should also be an area for urgent attention. A PIA-led national strategy would be an obvious step, and that strategy would necessarily include a communication and outreach program to secondary school students, as well as a properly resourced 
scholarship program targeted specifically at Aboriginal and Torres Strait Islander students. Recent steps taken by the Victorian Division of PIA in establishing Indigenous-specified scholarships for potential undergraduates could be considered as a model.

A clear problem is the lack of capacity within the planning education sector today to deliver these kinds of objectives. This will therefore require concerted action by PIA in collaboration with Australian Universities and Aboriginal communities to: develop and resource cultural safety training for planning educators; providing resources to educators for appropriate engagement and liaison with Indigenous communities to prepare teaching units and appropriate learning experiences; and appoint Indigenous representation on accreditation boards with the specific remit to support and guide the development of appropriate curricula.

A final necessary activity is the development of meaningful, sustained partnerships with Aboriginal and Torres Strait Islander communities across the planning community. Whitzman (this issue) also seeks to refine the collaborative planning approach, showing that co-designing the production of knowledge is just as important as collaborating on policy design. In any area of planning work this takes time, skill and resources. The demanding nature of this work is even more pronounced in relation to Indigenous peoples because of colonial legacies and a more pronounced difference sometimes between the values of western planning and Indigenous interests. Such partnerships work best when they are contextually-specific, in other words collaboratively designed to best suit local interests and needs. This will mean being prepared to work against the grain of standardized procedures and short timeframes and instead find opportunities to broker new relationships and catalyse alternative planning outcomes.

The steps briefly outlined here are by no means exhaustive. They are offered as suggestions for initial and urgent practical actions that must be taken across the planning community. It is an indictment that a profession concerned with placemaking and community building in a country such as Australia has no formal 
commitment or public discussion about its relationship with Indigenous people, no formal involvement of Aboriginal and Torres Strait Islander peoples in the strategic leadership of the profession, has made little effort towards making planning education and practice culturally safe and relevant for Indigenous people, has no strategy for getting Indigenous students into and successfully completing planning degrees, and has given no substantive consideration to what form the inclusion of Indigenous content in planning education should take. Planning in Australia is fundamentally out of step, in this regard, with the expectations of contemporary Aboriginal and Torres Strait Islander communities. It is long past time this situation was addressed.

\section{Acknowledgements}

The author would like to acknowledge the guest editors of this special issue for helpful comments, and Ed Wensing for continued collegial inspiration and specific comments on this article.

\section{References}

Altman, J., 2014. The political ecology and political economy of the Indigenous land titling "revolution" in Australia. Maori Law Review, Indigenous, pp.117.

Altman, J. \& Kerins, S., 2012. People on Country: Vital Landscapes, Indigenous Futures Federation Press, ed., Sydney.

Altman, J. \& Markham, F., 2015. Burgeoning Indigenous land ownership: Diverse values and strategic potentialities. In S. Brennan et al., eds. From Mabo to Akibo: A vehicle for change and empowerment? Sydney: The Federation Press.

Anderson, K., 1993. Place narratives and the origins of inner Sydney's Aboriginal settlement, 1972-3. Journal of Historical Geography, 19(3), pp.314-335.

Barry, J., 2012. Indigenous-State planning as inter-institutional capacity development: the evolution of 'government-to-government relations in coastal British Columbia, Canada. Planning Theory and Practice, 13(2), pp.213-231. 
Bawaka Country et al., 2016. Co-becoming Bawaka: Towards a relational understanding of space/place. Progress in Human Geography, 40(4), pp.455475 .

Blomley, N., 2004. Unsettling the city: Urban land and the politics of property, New York: Routledge.

Brennan, S., Davis, M., Edgeworth, B. \& Terrill, L., 2015. Native Title from Mabo to Akiba: A vehicle for change and empowerment?, Annanndale: Federation Press.

Byrne, D.R., 1996. Deep Nation: Australia's Acquisition of an Indigenous Past. Aboriginal History, 20, pp.82-107.

Byrne, D.R., 2003. Nervous landscapes. Journal of Social Archaeology, 3(2), pp.169-193.

Byrne, J. \& Houston, D., 2005. Ghosts in the city: Multicultural redevelopment and urban memory in East Perth. In D. Cryle \& J. Hillier, eds. Consent and Consensus: Politics, Media and Governance in Twentieth Century Australia. Perth: API Network, Curtin University of Technology.

Carter, P., 1987. The Road to Botany Bay: An Essay in Spatial History, Boston: Faber.

Churchill, W., 2011. A Travesty of a Mockery of a Sham: Colonialism as "SelfDetermination" in the UN Declaration on the Rights of Indigenous Peoples. Griffith Law Review, 20(September), p.526.

Colman, J., 1984. EAROPH Congress 21024 August 1984. Australian Planner, p.29.

Coulthard, G., 2014. Red Skins, White Masks: Rejecting the colonial politics of recognition, Minneapolis: University of Minnesota Press.

Dorsett, S., 1995. Civilisation and cultivation: colonial policy and Indigenous people in Canada and Australia. Griffith Law Review, (4).

Foley, G. \& Anderson, T., 2006. Land Rights and Aboriginal Sovereignty. Australian Journal of Human Rights, 12(3), pp.83-108.

Government of Victoria, 2014. Plan Melbourne, Melbourne.

Harris, C., 2002. Making native space: Colonialism, resistance, and reserves in British Columbia, Vancouver: UBC Press.

Hillyer, V., 2007. Urban Policy and Research Bennett house : Aboriginal heritage as real estate in East Perth. Urban Policy and Research, 19(2), pp.147-182. 
Howitt, R., 2006. Scales of coexistence: Tackling the tension between legal and cultural landscapes in post-Mabo Australia. Macquarie Law Journal, 6, pp.49-64.

Howitt, R., Doohan, K., Suchet-Pearson, S., Lunkapis, G., Muller, S., Lawrence, R., Prout, S., Veland, S. \& Cross, S., 2013. Capacity Deficits at Cultural Interfaces of Land and Sea Governance. In R. Walker, D. Natcher, \& T. Jojola, eds. Reclaiming Indigenous Planning. McGill-Queen University Press, pp. 313338.

Howitt, R. \& Lunkapis, G.J., 2010. Coexistence: Planning and the challenge of Indigenous Rights. In J. Hillier \& P. Healey, eds. The Ashgate Research Companion to Planning Theory: Conceptual Challenges for Spatial Planning. Farnham: Ashgate.

Jackson, S., 1997. A Disturbing Story: The fiction of rationality in land use planning in Aboriginal Australia. Australian Planner, 34(4), pp.221-226.

Jackson, S., 1998. Geographies of Co-existence: Native title, cultural difference and the decolonisation of planning in North Australia. Thesis. NSW: Macquarie University.

Jackson, S., 1996. Town Country: Urban development and Aboriginal land and sea rights in Australia. In R. Howitt, J. Connell, \& P. Hirsch, eds. Resources, Nations and Indigenous Peoples: Case studies from Australasia, Melanesia and Southeast Asia. Melbourne: Oxford University Press, pp. 90-103.

Jojola, T., 2008. Indigenous Planning: An emerging context. Canadian Journal of Urban Research, 17(Supplement), pp.37-47.

Maclean, M., 1997. Executive Brief. Australian Planner, pp.184-186.

Matunga, H., 2013. Theorizing Indigenous Planning. In R. Walker, T. Jojola, \& D. Natcher, eds. Reclaiming Indigenous Planning. McGill-Queen University Press.

McGrath, P., 2016. The right to protect sites: Indigenous heritage management in the era of native title, Canberra: AIATSIS Research Publications.

Newcomb, S.T., 2011. The UN Declaration on the Rights of Indigenous Peoples and the Paradign of Domination. Gri, 20(March), p.578.

NSW Government, 2014. A Plan for Growing Sydney, Sydney.

Peters, E. \& Walker, R., 2005. Indigeneity and Marginalisation: Planning for and 
with Urban Aboriginal Communities in Canada. Progress in Planning, 63, pp.327-404.

Porter, L., 2006a. Planning in (Post)Colonial Settings: Challenges for Theory and Practice. Planning Theory \& Practice, 7(4), pp.383-396.

Porter, L., 2006b. Planning in (post)colonial settings: Challenges for theory and practice. Planning Theory and Practice, 7(4), pp.383-396.

Porter, L., 2010. Unlearning the Colonial Cultures of Planning, Alderstho: Ashgate.

Porter, L. \& Barry, J., 2014. Bounded recognition: Urban planning and the textual mediation of Indigenous rights in Canada and Australia. Critical Policy Studies, 10.1080/19.

Porter, L. \& Barry, J., 2016. Planning for coexistence: Recognizing Indigenous rights through land-use planning in Canada and Australia, London: Routledge.

Povinelli, E.A., 2002. The cunning of recognition: Indigenous alterities and the making of Australian multiculturalism, Michigan: Duke University Press.

Rose, D., 1996. Nourishing Terrains: Australian Aboriginal Views of Landscape and Wilderness, Canberra: Australian Heritage Commission.

Ryan, S., 1996. The Cartographic Eye: How explorers saw Australia, Melbourne: Cambridge University Press.

Sandercock, L., 1998. Making the invisible visible: A multicultural planning history.

Sandercock, L. \& Attili, G., 2010. Finding Our Way, Canada: Moving Images Distribution.

Sheehan, J. \& Wensing, E., 1998. Indigenous Property Rights: New developments for planning and valuation, Canberra.

Smith, L., 2000. A History of Aboriginal Heritage Legislation in South-Eastern Australia. Australian Archaeology, (50), pp.109-118.

Smith, L., 2004. Archaeological theory and the politics of cultural heritage, London: Routledge.

Stuart, K. \& Thompson-Fawcett, M., 2010. Taone Tupu Ora: Indigenous knowledge and sustainable urban design, Wellington: Steele Roberts Aotearoa.

Taylor, E. \& Hurley, J., 2015. “Not a Lot of People Read the Stuff.” Australian Urban Research in Planning Practice. Urban Policy and Research. 
Walker, R., Jojola, T. \& Natcher, D., 2013. Reclaiming Indigenous Planning, McGillQueen University Press.

Watson, I., 2015. Aboriginal Peoples, Colonialism and International Law, London: Routledge.

Watson, I., 2011. The 2007 Declaration on the Rights ofIndigenous People: Indigenous Survival - Where to from here? Griffith Law Review, 20(3).

Weaver, J.C., 1996. Beyond the fatal shore: Pastoral squatting and the occupation of Australia, 1826 to 1852. American Historical Review, 101(4), pp.9811007.

Wensing, E., 2013. A just accommodation of Aboriginal relationships to "country" in environmental planning. In J. Byrne, J. Dodson, \& N. Sipe, eds. Australian Environmental Planning: Challenges and Future Prospects. London: Routledge.

Wensing, E., 2012. Aboriginal and Torres Strait Islander Australians. In S. Thompson \& P. Maginn, eds. Planning Australia 2nd edition: An overview of urban and regional planning. Melbourne: Cambridge University Press.

Wensing, E., 2016. Indigenous rights in land use planning strengthened in Queensland. Native Title Newsletter.

Wensing, E. \& Porter, L., 2015. Unsettling planning's paradigms: towards a just accommodation of Indigenous rights and interests in Australian urban planning? Australian Planner, 3682(December), pp.1-12.

Wensing, E. \& Sheehan, J., 1997. Native Title: Implications for Land Management, The Australia Institute. 